\title{
Ethnologies
}

\section{Culinary Tourism. By Lucy M. Long, ed. (Lexington: University Press of Kentucky, 2004. Pp. xiv + 306, ISBN 0-8131-2292-9)}

\section{Diane Tye}

Volume 28, numéro 2, 2006

Les noces en vrai

Wedding Realities

URI : https://id.erudit.org/iderudit/014992ar

DOI : https://doi.org/10.7202/014992ar

Aller au sommaire du numéro

\section{Éditeur(s)}

Association Canadienne d'Ethnologie et de Folklore

ISSN

1481-5974 (imprimé)

1708-0401 (numérique)

Découvrir la revue

Citer ce compte rendu

Tye, D. (2006). Compte rendu de [Culinary Tourism. By Lucy M. Long, ed.

(Lexington: University Press of Kentucky, 2004. Pp. xiv + 306, ISBN

0-8131-2292-9)]. Ethnologies, 28(2), 229-230. https://doi.org/10.7202/014992ar

Ce document est protégé par la loi sur le droit d'auteur. L'utilisation des services d'Érudit (y compris la reproduction) est assujettie à sa politique d'utilisation que vous pouvez consulter en ligne.

https://apropos.erudit.org/fr/usagers/politique-dutilisation/
Cet article est diffusé et préservé par Érudit.

Érudit est un consortium interuniversitaire sans but lucratif composé de l'Université de Montréal, l'Université Laval et l'Université du Québec à Montréal. Il a pour mission la promotion et la valorisation de la recherche. https://www.erudit.org/fr/ 
of storytelling as it clearly, as it should, demonstrates the importance of interdisciplinary and intercultural perspectives.

This volume is indeed pertinent and appropriate for anyone who has an interest in language and culture. It is an easy, enjoyable, and comfortable read. You will not regret having read Blayer and Sanchez's Storytelling.

J. Joseph Edgette

Widener University

Chester, Pennsylvania

Culinary Tourism. By Lucy M. Long, ed. (Lexington: University Press of Kentucky, 2004. Pp. xiv + 306, ISBN 0-8131-2292-9)

This volume of twelve essays edited by Lucy M. Long brings together an impressive collection of established and emerging foodways scholars. In defining and developing the concept of culinary tourism, it is an important publication.

The book opens with a short foreword by Barbara KirshenblattKimblett and an introductory article by Lucy Long that traces the development of culinary tourism. Long encourages broadening the notion and her definition pushes boundaries. According to Long, culinary tourism is not just food for the tourist, but rather "the intentional, exploratory participation in the foodways of another - participation including the consumption, preparation, and presentation of a food item, cuisine, meal system, or eating style considered to belong to a culinary system not one's own" (21). We engage in culinary tourism at home and in the food court as well as when we travel.

Building on this definition, Long and the other contributors offer several valuable interpretive typologies for types of otherness, foodways, venues for tourism, and strategies for negotiating otherness in cultural tourism (11). For example, in the context of foodways, Long suggests analysing "otherness" along two perpendicular axes: the first runs from Edible/Palatable to Inedible/Unpalatable while the second, intersecting continuum, extends from Exotic to Familiar. These analytic guides provide useful tools. 
Articles offer a broad sampling of cross-cultural explorations of culinary tourism in three kinds of contexts: public and commercial; private and domestic; and constructed and emerging. Papers focussing on public contexts examine venues where food is not only being presented but is sold to outsiders: Thai restaurants, an Hawaiian festival, tourist industry's uses of Mexican food, and Jewish food in contemporary Poland. Essays on culinary tourism in domestic contexts centre on familiar, informal settings where food is shared among family and friends. These papers explore an equally impressive spread as those in the first section, from aspects of Jewish and Basque American foodways to the experiences of Mormon missionaries in Guatemala. Finally, articles on culinary tourism in emerging contexts consider settings that are not historically bound but are actively being invented and negotiated. Studies focus on newer examples, examining southwestern American cuisine, the dynamics of ethnic foods in American contexts (the Catskills, Kansas, and Wisconsin), and baby boomers' attraction to Asian food. Articles in all three sections underline food's links to politics and explore culinary tourism's connections to constructions of authenticity, memory, and most centrally, otherness.

One leaves Culinary Tourism with a deeper understanding of some of food's complex relationships to the politics of culture. Although this collection feels more like a necessary foundation than an exciting departure, the book will undoubtedly serve as an important springboard for future work that further develops the interpretative challenges it introduces.

Diane Tye Memorial University St. John's, Newfoundland

\section{Performing Ethnomusicology: Teaching and Representation in World Music Ensembles. By Ted Solís, ed. (Berkeley, Los Angeles and London: University of California Press, 2004. Pp. Vii + 322, index, ISBN 052023831 1) \\ Performing Ethnomusicology is arguably the first anthology to deal with the hot topics that surround Western organized world music ensembles. Weaving together excellent scholarship from a variety of sources, this is a collection of sixteen essays which explores a plethora}

